Resumen por el autor, Charles Zeleny.

Universidad de Illinois.

Un cambio en el gene 'bar'1 en Drosophila melanogaster, disminución del número de facetas y aumento de dominancia.

Durante la selección de individuos con un número bajo facetas oculares, en moscas que poseen ojos blancos en forma de banda, apareció un solo macho cuyo ojo presentaba solamente 19 facetas, en vez del número medio 75.6 presente en los demás machos de la misma generación. Cuando se cruzó este macho con hembras de su misma generación produjo, en la tercera generación de híbridos, una raza cuyo número medio de facetas es 23. Esta raza se ha conservado sin cambiar durante dos años, y el autor propone para ella el nombre de 'ultra-bar.' La mutación mencionada es interesante porque tiene lugar en la misma dirección que la mutación original que transformó el ojo completo en ojo en forma de banda, y es un cambio en el mismo gene, mientras que otras mutaciones que afectan al mismo carácter, exceptuando la reversión a ojo completo, se deben a factores accesorios. Además dicha mutación ha aparecido en la misma dirección de la selección verificada por el autor. Finalmente, presenta una dominancia considerablemente aumentada, de tal modo que no solo es dominante sobre el ojo completo sino también sobre el ojo en forma de banda.

${ }^{1}$ Con este nombre se designa una mutacion en la cual la porcion pigmentada del ojo aparece en forma de banda vertical. Nos parece oportuno conservar la palabra original inglesa con el fín de no cambiar los símbolos empleados en las fórmulas. (N. del T.)

Translation by Jose F. Nonidez

Carnegie Institution of Washington 


\section{A CHANGE IN THE BAR GENE OF DROSOPHILA MELANOGASTER INVOLVING FURTHER DECREASE IN FACET NUMBER AND INCREASE IN DOMINANCE ${ }^{1}$}

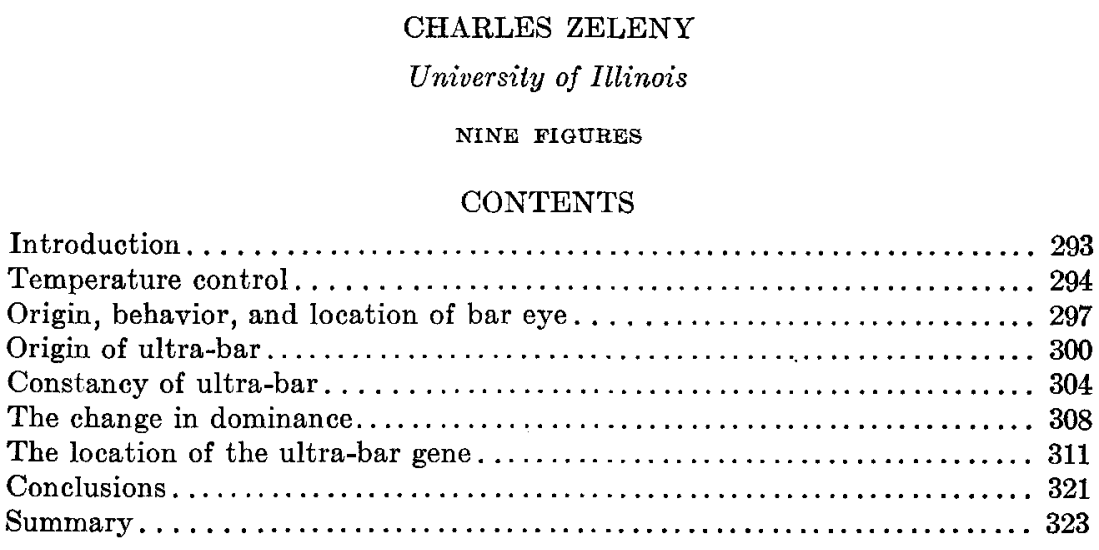

\section{INTRODUCTION}

In connection with a study of the germinal and environmental factors affecting eye-facet number in Drosophila melanogaster, which is in progress in the Zoological Laboratory at the University of Illinois, several interesting germinal changes have been observed. Some of these involve accessory factors while others are changes in the bar gene itself. Among the latter is the reverse mutation to full eye first described by H. G. May ('17) and since then observed several times by the writer. The change to be described is equally interesting. It appeared in the second low selection for facet number in white bar and involves further decrease in facet number. Like reverse mutation, it is due to a change in the bar gene itself, and not to the appearance of an accessory factor; it is in the same direction as the original bar

${ }^{1}$ Contributions from the Zoological Laboratory of the University of Illinois, no. 149 . 
mutation of full eye; it is in the same direction as the selection which was being carried on in the material, and, lastly, it has a greatly increased dominance, so that it is dominant not only over full eye, but also over bar eye.

\section{TEMPERATURE CONTROL}

Eye-facet number in Drosophila has exceptional advantages in a quantitative study of both germinal and environmental factors. The earlier studies of the germinal factors affecting this character by Zeleny and Mattoon ('15) and H. G. May ('17) were made difficult and unsatisfactory in many ways because of the disturbing presence of uncontrolled environmental factors, and it was realized that the latter must be eliminated in considerable degree before further progress could be made with the former. Experiments in this laboratory by Seyster ('19) and Krafka ('20) have shown that temperature is the most important of these factors. It affects facet number in a marked and definite manner. Adequate facilities for temperature control in the Vivarium Building have made possible the analysis of the germinal factors preexisting in the bar stocks and also the isolation of new factors as they arise.

All of the facet numbers recorded in the present paper were from individuals raised at $27^{\circ} \pm 0.5^{\circ}$. The incubator used was no. 2, made by the Chicago Surgical and Electrical Company. The heat unit is a high-resistance wire coil and contact is accomplished by the bending of a diaphragm. The platinum contact points must be kept clean. A test of the incubator as purchased showed that there was a difference of three or more degrees in the different parts of the chamber. A 12-inch General Electric desk fan with lengthened shaft so that it could be installed with the motor outside and the blades inside of the chamber has acted in a satisfactory manner in keeping the air stirred. Frequent checks were made of the temperature of the banana food in which the larvae were developing, which showed that under these conditions the food temperature differed from the air temperature by two-tenths of a degree at most. A Tycos, ribbon type, birecord thermometer made by the Taylor Instrument Company 
of Rochester, New York, was used for a continuous record of the temperature. This shows, for the period covered by the present experiments, a departure from $27^{\circ}$ not exceeding $0.5^{\circ}$. The accessory tests make it probable that this applies to the temperature of the larvae as well as to that of the thermometer bulb.

The satisfactory character of the incubator was in part due to its being placed in a room with both refrigeration and heat control and maintained at $24^{\circ}$ with an extreme departure of $1^{\circ}$. This constant-temperature room is cooled by air blown over brine coils and warmed by steam coils. Both systems are under automatic control installed by the Johnson Service Company of Milwaukee.

In choosing a suitable constant temperature for the experiments with germinal factors affecting facet number in the bar stocks, the primary consideration was based upon the fact that facet number decreases very strikingly with increase in temperature, and facility and accuracy in counting are of course easier the smaller the number of facets. An added inducement for using a warm temperature is the shorter developmental period. The choice of the exact temperature was more difficult. It was desired to go as high as possible without noticeable disturbance of the viability and without subjecting the work to the criticism that any germinal changes observed are the results of violent reactions to unfavorable conditions. Twenty-seven degrees centigrade was chosen after a preliminary trial had shown that at $29^{\circ}$ viability is considerably lowered.

Flies raised in dry food frequently are much smaller than those raised in moist food, but preliminary counts under these conditions show no consistent difference in eye-facet number between the two. In figure 1 it is noticed that the magnification in each of the five cases is the same and that the size of individual facets is in general larger the larger the individual fly. In individuals of uniform size, however, as found in stocks raised under optimum conditions, the number of facets is proportional to the area of the eye as shown by Seyster ('19).

In striving for the ideal of basic stocks which will give perfectly constant facet numbers and in which any departure, no matter 


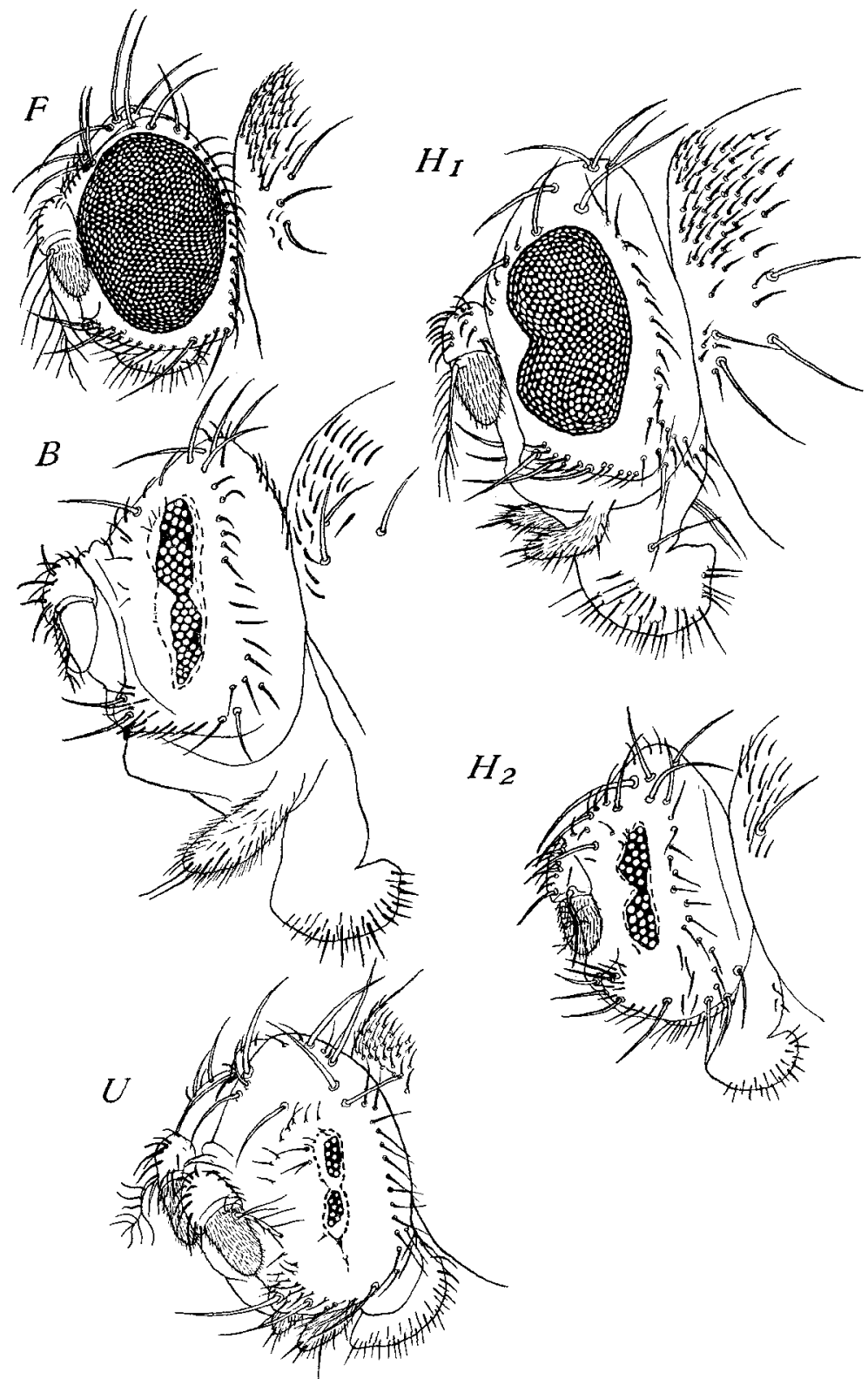

Fig. 1 Full-eye, bar, ultra-bar, and their heterozygotes. $F$, full-eye wild females. $B$, white-bar female of the second generation of low selection from which ultra-bar was derived by mutation (culture no. 144.2). $U$, ultra-bar female (no. 158.1). $H_{1}$, heterozygous female from full $\times$ bar. (no. 87.11). $H_{2}$, heterozygous female from full $\times$ ultra-bar (no. 259.3). $\times 60$. 
how small can be definitely ascribed either to a particular germinal or a particular environmental change, only a start has been made. However, analysis of the one group of factors facilitates the investigation of the other. All the material described in the present paper is preserved in alcohol as far as possible and is accessible for future reference. This explains the use of culture numbers in the descriptions.

\section{ORIGIN, BEHAVIOR AND LOCATION OF BAR EYE}

As described by Tice ('14), bar-eye appeared in a single male in a stock with full eyes. In one of my wild stocks, no. 345 , full

TABLE 1

Comparison of full eye, bar, and ultra-bar, at $27^{\circ} \mathrm{C}$. Females. The class distributions in the same populations are given in table $g$ and figure 8

\begin{tabular}{|c|c|c|c|}
\hline & FULL EYE ${ }^{1}$ & BAR SECOND LOW ${ }^{2}$ & ULTRA-BAR \\
\hline Catalog number...... & 345 & 144,145 & $\begin{array}{r}158-499 \\
772-799\end{array}$ \\
\hline Date............. & $1918 \times 29$ & $1917 \times 9-26$ & $\begin{array}{l}1917 \text { XII } 14- \\
1918 \text { VII } 23\end{array}$ \\
\hline Number of individuals..... & 10 & 179 & 1590 \\
\hline Mean in factorial units ${ }^{3} \ldots$. & $+26.67 \pm 0.24$ & $+0.74 \pm 0.11$ & $-9.79 \pm 0.03$ \\
\hline $\begin{array}{l}\text { Standard deviation }(=\text { coef- } \\
\text { ficient of variability }) \text { in fac- } \\
\text { torial units }{ }^{4} \ldots \ldots \ldots \ldots \ldots\end{array}$ & $1.11 \pm 0.17$ & $2.25 \pm 0.08$ & $1.62 \pm 0.02$ \\
\hline $\begin{array}{l}\text { Lowest individual in factorial } \\
\text { units . . . . . . . . . }\end{array}$ & +24.22 & -5.60 & -15.93 \\
\hline $\begin{array}{l}\text { Highest individual in factor- } \\
\text { ial units } \ldots \ldots \ldots \ldots \ldots \ldots\end{array}$ & +28.02 & +7.61 & -4.60 \\
\hline Mean of facets............ & 810.6 & $61.8 \pm 0.7$ & $21.96 \pm 0.06$ \\
\hline Lowest facet number. . . . . . & 632 & 32 & 11 \\
\hline Highest facet number...... & 924 & 119 & 35 \\
\hline
\end{tabular}

${ }^{1}$ With the small number of cases represented under full eye, the standard deviation and probable error determinations of course have no great significance. The values given are those obtained by following the usual methods employed when larger numbers of cases are available. They may, however, indicate in a very general way the probable variability of the stock as compared with the others.

${ }^{2}$ Second low selected generation including all matings.

: A factorial unit is one that produces a 10 per cent change in facet number.

${ }^{4}$ According to the method used, standard deviation is directly a measure of variability and may be used as a coefficient of factorial variability. 
eye has an average of 810.6 facets in the females and 849.8 facets in the males (tables 1 to 4 ). The unselected red-bar stock, as obtained by Zeleny and Mattoon ('15) for their selection work, has an average of 65.1 facets for the females and 98 for the males. The unselected white-bar stock (nos. 144 and 145) which served as the starting point of the selection line in which ultra-bar origi-

TABLE 2

Comparison of full eye, bar, and ultra-bar at $27^{\circ} \mathrm{C}$. Males. The class distributions in the same population are given in table 4 and figure 3

\begin{tabular}{|c|c|c|c|}
\hline & FULL EYE 1 & BAR SECOND LOW ${ }^{2}$ & ULTRA-BAR \\
\hline Catalog number .......... & 345 & 144,145 & $\begin{array}{r}158-499 \\
772-799\end{array}$ \\
\hline 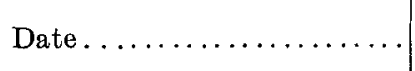 & $1918 \times 29$ & $1917 \times 9-26$ & $\begin{array}{l}1917 \text { XII } 14- \\
1918 \text { VII } 23\end{array}$ \\
\hline Number of individuals. . ... & 10 & 157 & 1594 \\
\hline $\begin{array}{l}\text { Mean in factorial units...... } \\
\text { Standard deviation in factor- }\end{array}$ & $+21.15 \pm 0.23$ & $-3.44 \pm 0.14$ & $-14.96 \pm 0.03$ \\
\hline $\begin{array}{r}\text { ial units. . . . . . . . . . . } \\
\text { Lowest individual in factorial }\end{array}$ & $1.12 \pm 0.17$ & $2.54 \pm 0.09$ & $1.51 \pm 0.02$ \\
\hline $\begin{array}{r}\text { units } \ldots \ldots \ldots \ldots \ldots \ldots \\
\text { Highest individual in factor- }\end{array}$ & +19.12 & -9.17 & -21.05 \\
\hline ial units. . . . . . . . . . & +22.49 & +2.63 & -9.42 \\
\hline Mean of faeets............ & 849.8 & $75.6 \pm 1.0$ & $23.04 \pm 0.06$ \\
\hline Lowest facet number. . . & 700 & 41 & 12 \\
\hline Highest facet number ...... & 980 & 134 & 40 \\
\hline
\end{tabular}

1 With the small number of cases represented under full eye, the standard deviation and probable error determinations of course have no great significance. The values given are those obtained by following the usual methods employed when larger numbers of cases are available. They may, however, indicate in a very general way the probable variability of the stock as compared with the others.

Second low selected generation including all matings and excluding the 19facet male from which the ultra bar stock was derived.

nated had an average of 58.8 facets for the females and 111.4 for the males. In the white bar this represents a change of -26.67 factorial units in the females and -21.15 in the males, according to the system of tabulation used in the present paper and described briefly on page 309 and more fully in a separate paper which is in preparation. A factorial unit is one that produces a 10 per cent change in facet number. 


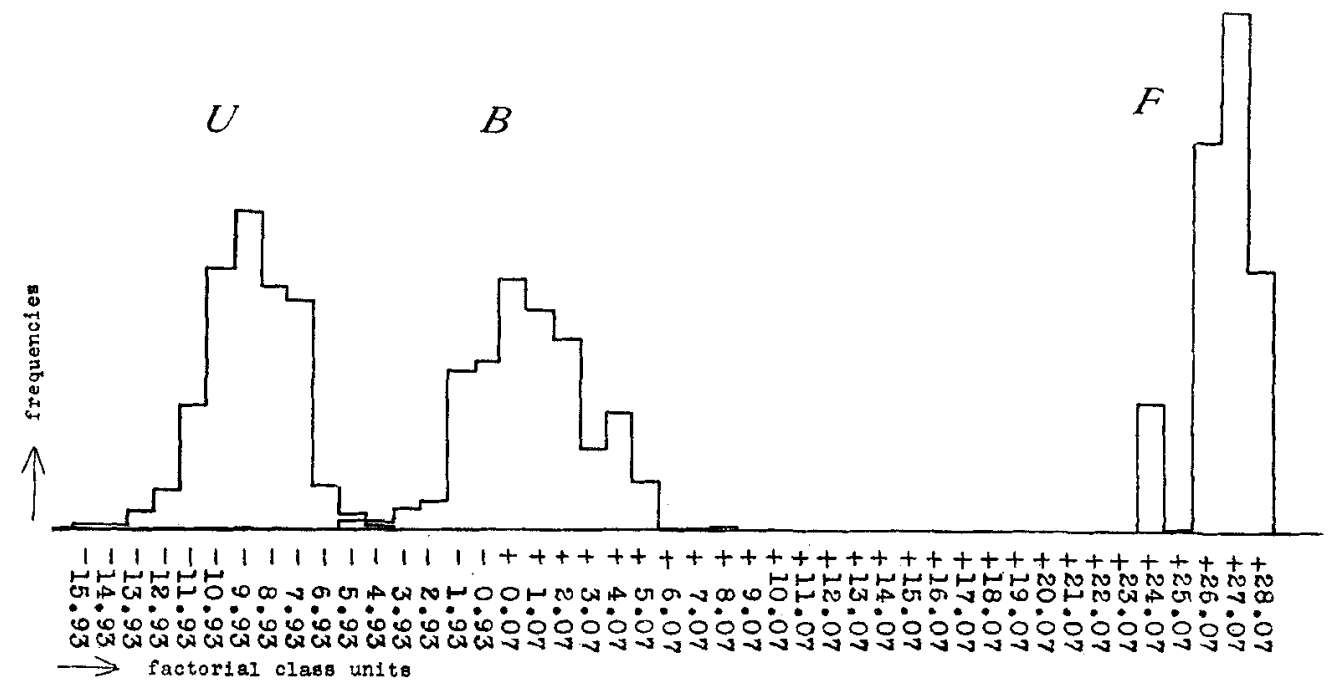

Fig. 2 The class distributions according to factorial units affecting facet numbers in populations of ultra-bar females $(U)$, bar females of the second low selected white-eyed generation from which ultra-bar was derived $(B)$, and fulleye $(F)$. The class frequencies are in per cents of the whole population and are therefore directly comparable. The zero of the factorial scale is the mean value of the unselected white bar. The same material is represented in tables 1 and 3 .

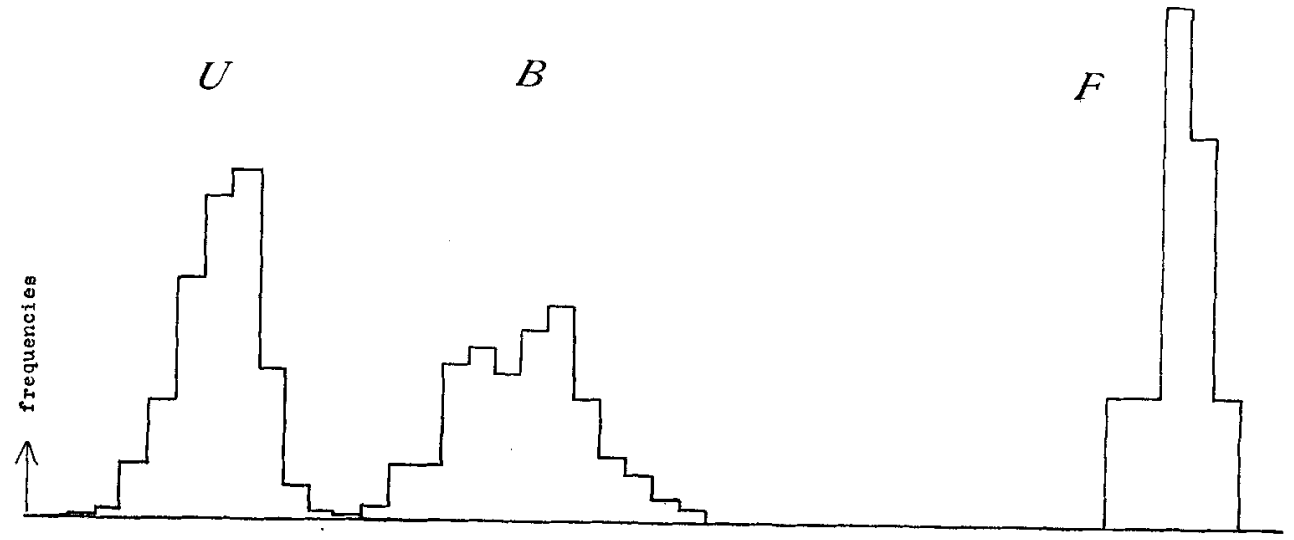

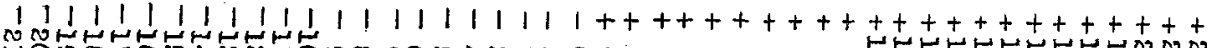

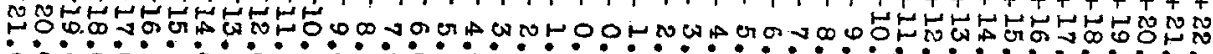

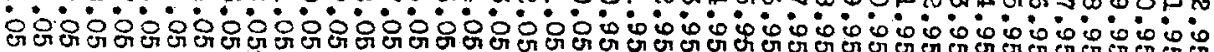
factorial ciass units

Fig. 3 The class distributions for males. The same material is represented in tables 2 and 4 . 
Tice further located the gene for bar eye in the sex chromosome, and on the basis of percentage of crossing over with other sexlinked factors it was put at 57 cross-over units from yellow. She considered bar as a dominant to full eye, and it is so described in various papers by Morgan and others. Strictly speaking, the heterozygous condition is intermediate between bar and full. According to the method used here, the heterozygotes between low bar (F 24) and full are +23.89 factorial units from bar and only -7.23 such units from full (table 7 ). If 100 per cent represents a condition of complete dominance and 0 per cent of complete recessiveness, bar has a dominance coefficient of 23.2 per cent and full of 76.8 per cent. If either is to be considered as a dominant, the term should be applied to full eye rather than to bar eye.

Bar eye has a high degree of stability, though there is an occasional mutation such as the reverse mutation to full. Such reverse mutations are apparently actual returns of the gene to the original condition. The writer has noticed several of them in his stocks and several other germinal changes, among which is the one described in the present paper.

\section{THE ORIGIN OF ULTRA-BAR}

Ultra-bar also appeared in a single male. This male with but 19 facets appeared in the second low selected generation of the white-bar line on October 20, 1917. A cross with a 44-facet sister gave a pure stock in $\mathrm{F}_{3}$. The ultra-bar thus established has remained stable in character except for the mutations described on page $304 \mathrm{ff}$.

The average facet number is 21.96 in the females and 23.04 in the males as opposed to 61.8 and 75.6 in the second low generation of white bar from which it was derived and 810.6 and 849.8 in the full eye. In factorial units the second low generation of the white-bar line is -25.93 and -24.59 units from full. Ultrabar is -10.53 and -11.52 units from the second low generation of white bar and -36.46 and -36.11 units from full eye. Typical representatives of full eye, bar, and ultra-bar are shown in figure 1. Table 1 gives the values of the means, the ranges, and 
the standard deviations. In the case of factorial units the standard deviation may be used directly as the coefficient of variation. The values for full eve are based upon such a small number of cases wholly because of the tedious character of the count. In the bar stocks counts can be made by placing the flies on their sides on a small block of wood with a surface painted black and so inclined as to bring the eye facets in a horizontal plane under the microscope. The rows of facets can then be followed by the observer and counts can be made with a fair degree of accuracy. In practice there is, however, always a small per cent of error which increases with the facet number. In full eye the large number of facets combined with the curvature of the eye makes this procedure impossible. It is necessary to resort to the mounting of the eye on a slide under a cover-glass. The non-chitinous parts are removed with caustic potash and the faceted part mounted in Canada balsam and flattened out under a coverglass. With a high objective, a mechanical stage, and cross hairs in the ocular, it is possible to count the facets with a fair degree of accuracy, but it is not profitable to count a large number of individual eyes.

Tables 3 and 4 and figures 2 and 3 give comparisons of the range and variability of the three stocks in graphic form. There can be no question that the stocks are absolutely distinct. Bar and ultra-bar barely overlap in the females and not at all in the males. As shown in the tables, the variability of ultra-bar, here expressed directly by the standard deviation, is significantly less than that of the bar stock from which it was derived, and this difference between bar and ultra-bar remains throughout the selection generations. Figures 2 and 3 bring out the same point. The standard deviation value for tull eye of course has no special significance because of the small number of cases. It may perhaps indicate that full eye is less variable than bar. 
TABLE 3

Variability of full, bar, and ultra-bar Females

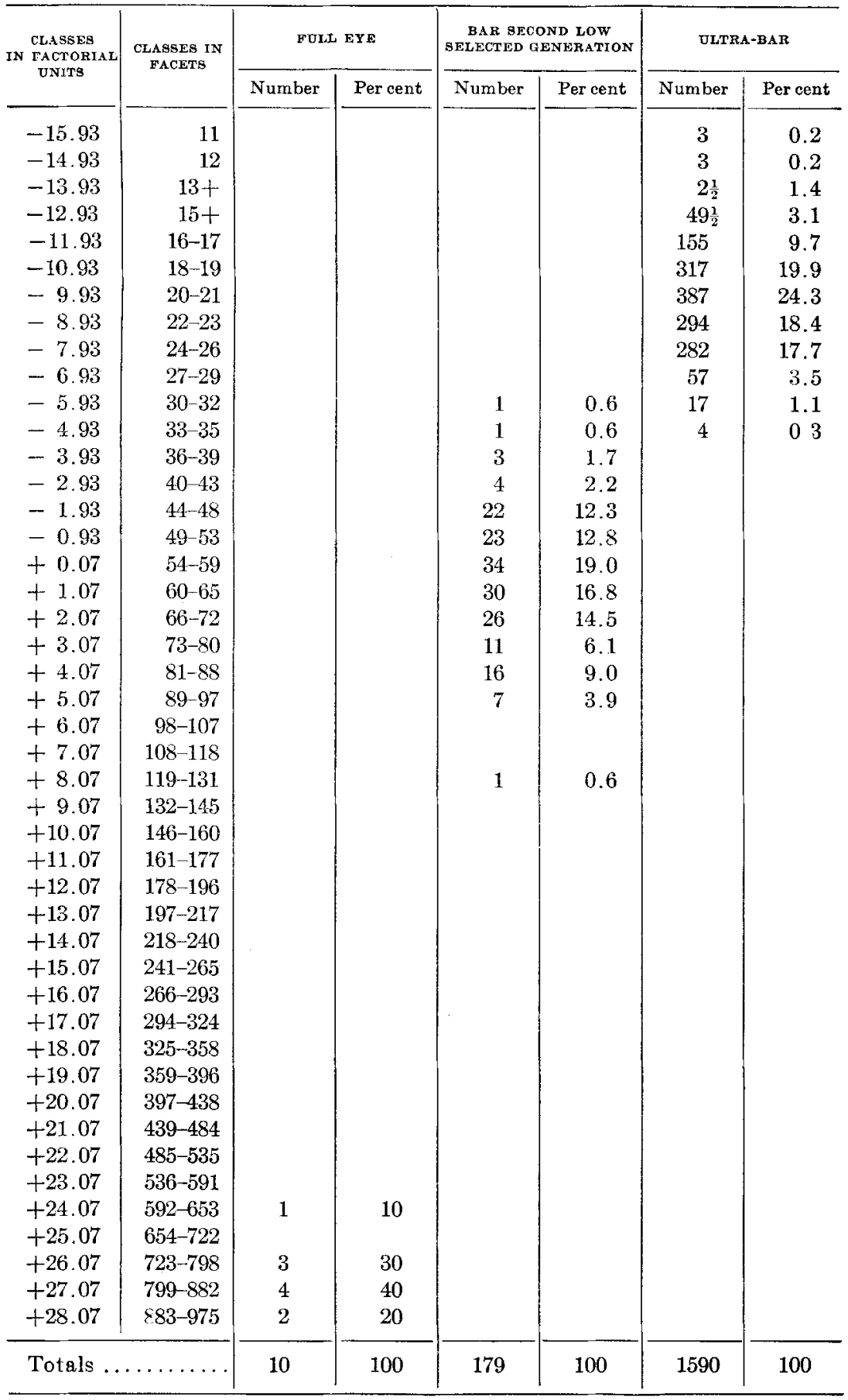


TABLE 4

Variability of full, bar, and ultra-bar. Males.

\begin{tabular}{|c|c|c|c|c|c|c|c|}
\hline \multirow{2}{*}{$\begin{array}{c}\text { CLASSES } \\
\text { IN FACTORIA } \\
\text { UNITS }\end{array}$} & \multirow{2}{*}{$\underset{\text { FACETS }}{\text { CLASSES IN }}$} & \multicolumn{2}{|c|}{ FULL EYE } & \multicolumn{2}{|c|}{$\begin{array}{c}\text { BAR SECOND LOW } \\
\text { SELECTED GENERATION }\end{array}$} & \multicolumn{2}{|c|}{ OLTRA-BAR } \\
\hline & & Number & Per cent & Number & Per cent & Number & Per cent \\
\hline-21.05 & 12 & & & & & 1 & 0.1 \\
\hline-20.05 & $13+$ & & & & & $2 \frac{1}{2}$ & 0.2 \\
\hline-19.05 & $15+$ & & & & & $12 \frac{\frac{1}{2}}{2}$ & 0.8 \\
\hline-18.05 & $16-17$ & & & & & 68 & 4.3 \\
\hline-17.05 & 18-19 & & & $1^{1}$ & 0.6 & 148 & 9.3 \\
\hline-16.05 & $20-21$ & & & & & 294 & 18.4 \\
\hline-15.05 & $22-23$ & & & & & 395 & 24.8 \\
\hline-14.05 & $24-26$ & & & & & 429 & 26.9 \\
\hline-13.05 & $27-29$ & & & & & 185 & 11.6 \\
\hline-12.05 & $30-32$ & & & & & 43 & 2.7 \\
\hline-11.05 & $33-35$ & & & & & 11 & 0.7 \\
\hline-10.05 & $36-39$ & & & & & 4 & 0.3 \\
\hline-9.05 & $40-43$ & & & 2 & 1.3 & 1 & 0.1 \\
\hline-8.05 & $44-48$ & & & 7 & 4.4 & & \\
\hline-7.05 & $49-53$ & & & 7 & 4.4 & & \\
\hline-6.05 & $54-59$ & & & 19 & 12.0 & & \\
\hline-5.05 & $60-65$ & & & 21 & 13.3 & & \\
\hline-4.05 & $66-72$ & & & 18 & 11.4 & & \\
\hline-3.05 & $73-80$ & & & 23 & 14.6 & & \\
\hline-2.05 & $81-88$ & & & 26 & 16.5 & & \\
\hline-1.05 & $89-97$ & & & 15 & 9.5 & & \\
\hline-0.05 & $98-107$ & & & 8 & 5.1 & & \\
\hline+0.95 & $108-118$ & & & 6 & 3.8 & & \\
\hline+1.95 & 119-131 & & & 3 & 1.9 & & \\
\hline+2.95 & $132-145$ & & & 2 & 1.3 & & \\
\hline+3.95 & $146-160$ & & & & & & \\
\hline+4.95 & $161-177$ & & & & & & \\
\hline+5.95 & $178-196$ & & & & & & \\
\hline+6.95 & $197-217$ & & & & & & \\
\hline+7.95 & $218-240$ & & & & & & \\
\hline+8.95 & $241-265$ & & & & & & \\
\hline+9.95 & $266-293$ & & & & & & \\
\hline+10.95 & $294-324$ & & & & & & \\
\hline+11.95 & $325-358$ & & & & & & \\
\hline+12.95 & $359-396$ & & & & & & \\
\hline+13.95 & $397-438$ & & & & & & \\
\hline+14.95 & $439-484$ & & & & & & \\
\hline+15.95 & $485-535$ & & & & & & \\
\hline+16.95 & $536-591$ & & & & & & \\
\hline+17.95 & $592-653$ & & & & & & \\
\hline+18.95 & $654-722$ & 1 & 10 & & & & \\
\hline+19.95 & $723-798$ & 1. & 10 & & & & \\
\hline+20.95 & 799882 & 4 & 40 & & & & \\
\hline+21.95 & $883-975$ & 3 & 30 & & & & \\
\hline+22.95 & $976-1078$ & 1 & 10 & & & & \\
\hline \multicolumn{2}{|l|}{ Totals. } & 10 & 100 & 158 & 100 & 1594 & 100 \\
\hline
\end{tabular}

1 The mutant from which the ultra-bar stock arose. 


\section{CONSTANCY OF ULTRA-BAR}

The single mutant male appeared on October 20, 1917, and the new stock was isolated in pure condition on December 27th. Numerous counts at $27^{\circ}$ show no essential change in character except for the mutants mentioned in a later paragraph. The mean, range, and standard deviation remain essentially unchanged. The data are given in tables 5 and 6 . During the period of establishment of the stock it was subjected to selection, but without any noticeable effect. There is no indication that this selection had any part in the production of the constancy. The selection data are treated in a separate paper. Later counts made during Julv, 1919, and not given in the tables show that the stock had remained without essential change for twenty months. The differences in the various cultures as shown in tables 5 and 6 are in some cases well within the probable error of random sampling, but in several cases the departures can not be explained in this way. For instance, take such a difference as that between the means of cultures no. 178 and no. 184 which is equal to 1.86 units. Its probable error, $\mathrm{E}_{\mathrm{D}}= \pm \sqrt{\mathrm{E}_{1}^{2}+\mathrm{E}_{2}^{2}}=$ \pm 0.17 , is only one-eleventh of the difference. Correspondingly, the difference in the males of the two cultures is 1.71 units and the probable error is 0.16 . These differences are therefore in all probability not due to random sampling. Their lack of permanence indicates that they are environmental and not germinal.

On four occasions individuals have appeared in the ultra-bar stock which differ markedly from the ordinary ones. Three of these may be considered as probably reverse mutations to full and the fourth as a new mutation upward in the direction of bar.

Mutant A. On July 9, 1918, there appeared in bottle no. 496.4 of the ultra-bar stock at $27^{\circ} \mathrm{C}$. a female with 46 facets in the left eye and 50 in the right eye. The upper limit of ultrabar stock females is 35 facets (table 5). It appeared that this female might be a heterozygote with one ultra-bar and one fulleye factor as the facet range of 54 such heterozygotes in test no. 357 , table 7, is 28 to 49 . Accordingly, she was mated with four 
of her brothers and gave according to expectation both full-eye and ultra-bar sons and ultra-bar and heterozygous daughters. Other crosses followed expectation in a similar manner.

That she is not the result of contamination is indicated, first, by the fact that she is white-eyed, and that hypothesis therefore necessitates contamination by a white full-eyed fly. Trap tests showed that there were no such flies free in the laboratory, though other kinds were caught. In the second place, only a single such individual appeared. Thirdly, the fact that she is a heterozygote makes it improbable that she is a stranger in the bottle. Fourthly, the general laboratory procedure is the same as that pursued when the reverse mutations of bar appeared, and the arguments given for those cases by May (1917) hold in this case also.

Deficiency tests were made. If a piece of the chromosome carrying the ultra-bar factor has dropped out, either the forked gene which is -0.5 units from ultra-bar or the fused gene which is +2.5 units away or both would in all probability be carried with it. When full males derived from a cross of the mutant female with ultra-bar males are mated with heterozygous fused females, they should give fused sons if there is deficiency on the plus side of ultra-bar. Such crosses gave no fused or forked sons and deficiency cannot be considered as the explanation of the mutant.

Mutant $B$. In a cross between wild red-eyed females and a 22 -facet white male from bottle no. 150 sp., 59 of the females were heterozygotes according to expectation and there was one full-eyed female. This exceptional female was crossed with wild red males and gave 23 full-eyed females and 25 full-eyed males. Both chromosomes therefore have the full-eyed factor, and the case is not due to a failure of the ultra-bar factor to dominate. Dr. A. H. Sturtevant has suggested that this may be a case of non-disjunction. Unfortunately the eye color was not recorded at the crucial point.

Mutant C. A single full-eyed white male appeared in the white ultra-bar stock no. 158.1 on December 26, 1917. It was shown by test no. 291.1 to be like ordinary full-eye, but no further tests were made. 


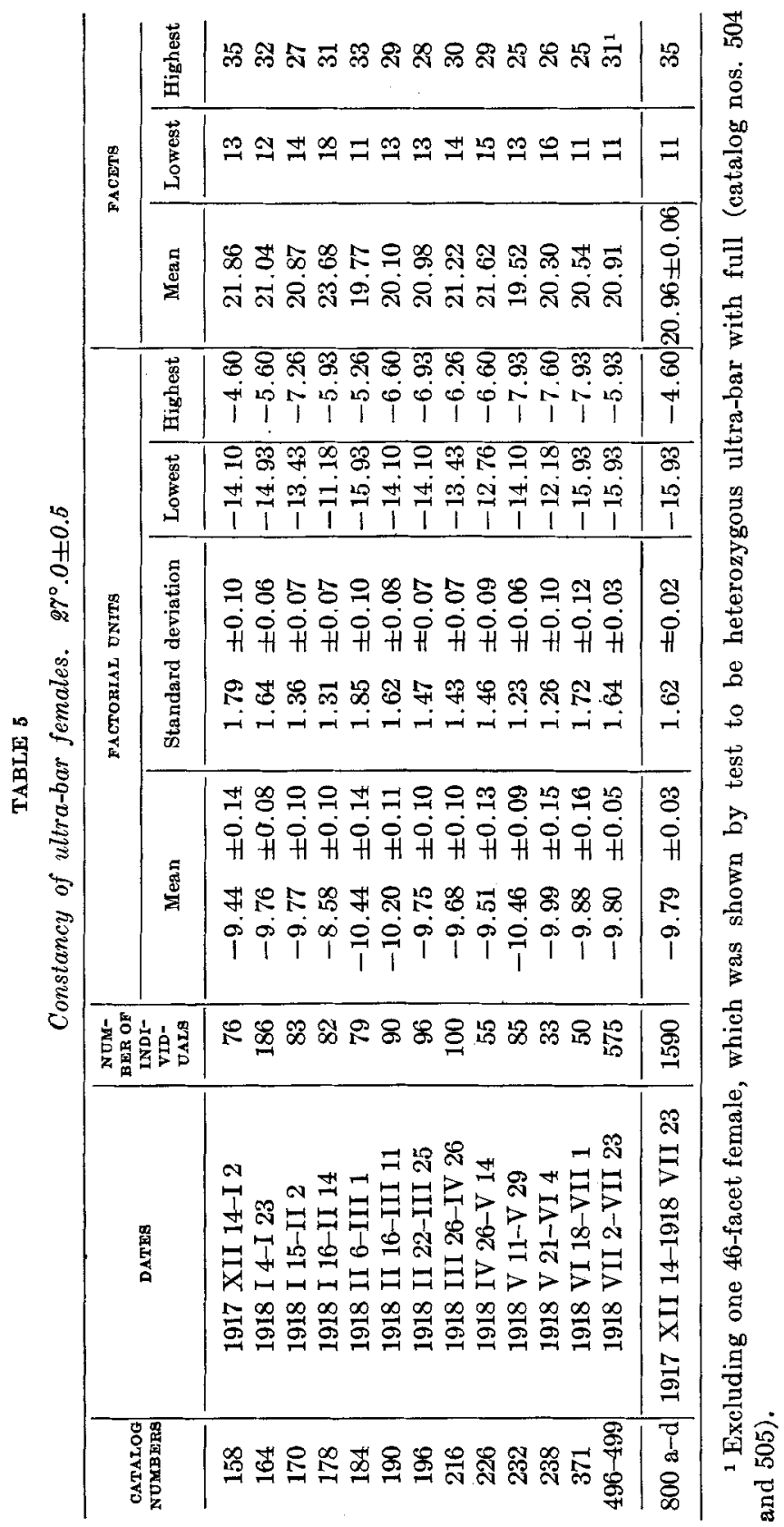




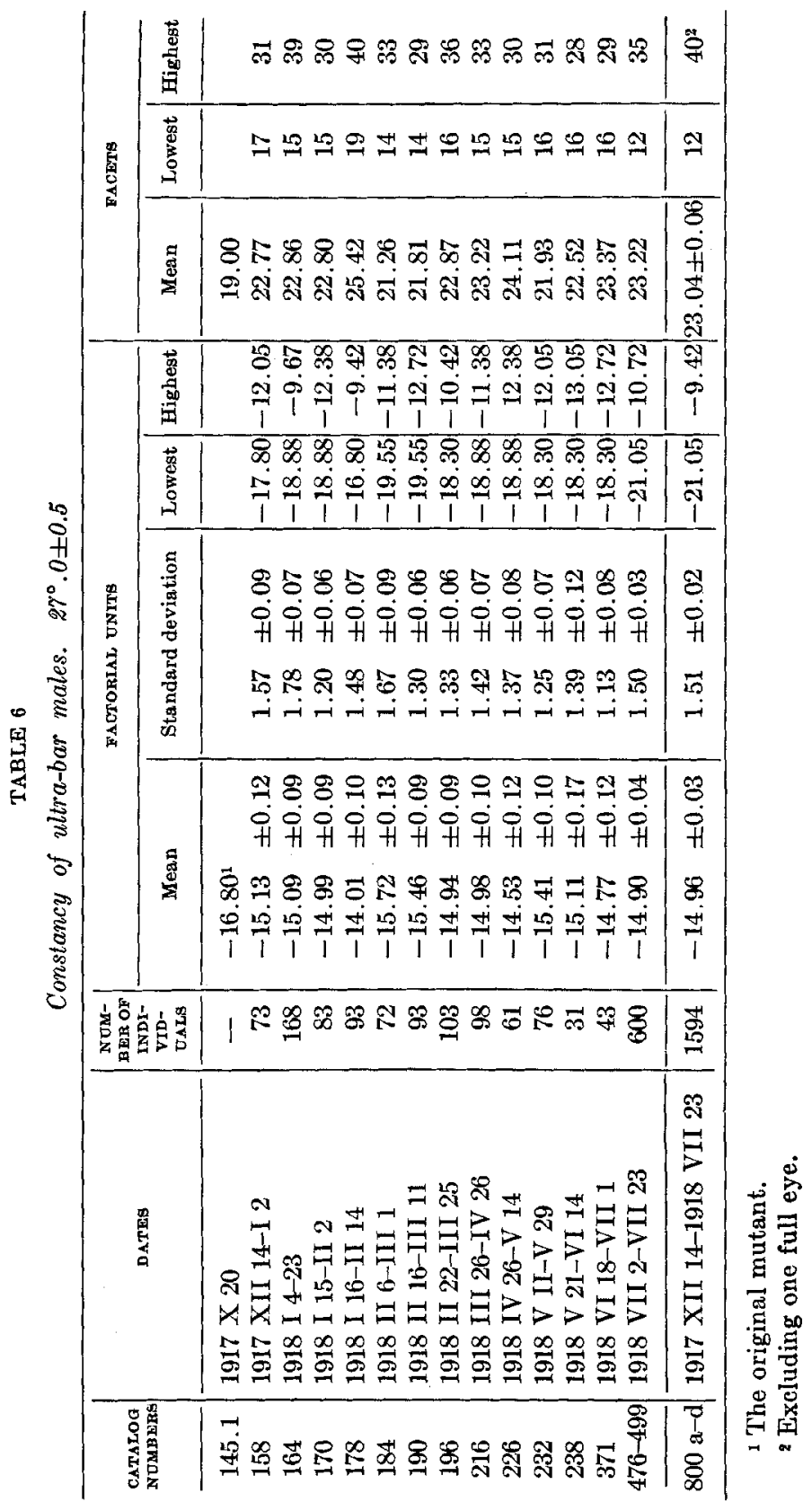


Mutant $D$. In bottle no. 196.2 of the ultra-bar stock there appeared on March 20,1918, both males and females with a facet number coming within the range of bar of the low selection line. When this particular mass culture was started on February 2,1918 , all the individuals were ultra-bar. The number of individuals with the new character makes it probable that the mutation occurred at least two generations before the first observation was made. A 62-facet and two 99-facet males were mated separately with full-eyed wild females and gave heterozygotes which differed from those of ultra-bar $x$ full and also of bar $\times$ full. The mean value in about five hundred flies as determined by an estimate without counts is very distinctly between the other two types of heterozygotes, and the range is extended so as to overlap their ranges. This extension of the range indicates the probable presence of accessory factors, but its limits make it seem that the new form is a mutation of ultra-bar in the direction of bar which is not exactly like bar.

Other cases that may be considered as mutations are given in the section on the determination of the locus of ultra-bar ( $p$ 311 ).

The frequency of occurrence of mutations in ultra-bar is about the same as that in bar, and the stability of the two stocks may be considered to be of about the same order.

\section{THE CHANGE IN DOMINANCE}

Even more striking than the difference in facet number between bar and ultra-bar is the difference in dominance. A heterozygote between ultra-bar and full comes very close to ultra-bar, while the heterozygote between bar and full is closer to full than to bar (fig. 1 and table 7). For purposes of comparison, the following method of determining the coefficient of dominance has been devised. Let $\mathrm{A}$ and $\mathrm{A}^{\prime}$ be the two members of an allelomorphic pair of factors, then the coefficient of dominance $\mathrm{C}_{\mathrm{D}}=\frac{\mathrm{AA}-\mathrm{AA}^{\prime}}{\mathrm{AA}-\mathrm{A}^{\prime} \mathrm{A}^{\prime}} \times 100$ in which $\mathrm{AA}$ and $\mathrm{A}^{\prime} \mathrm{A}^{\prime}$ are the mean values, respectively, of the homozygous stocks in factorial units and $\mathrm{AA}^{\prime}$ is the mean value of the heterozygous individuals. 
As discussed in a separate paper, the value of a factor or combination of factors affecting facet number is put on the basis of 10 per cent units. An arbitrary point, the mean facet. value in the unselected stock, is taken as the point of reference, and distribution classes are so arranged that the facet range of each class is 10 per cent of the mean facet value of that class. In this scheme any facet value may be represented as being a departure plus or minus a certain number of 10 per cent units from the point of reference. The method is based on the view that

TABLE 7

Dominance values in ultra-bar, bar, and full eye

\begin{tabular}{|c|c|c|c|c|c|c|}
\hline FEMALFA & $\begin{array}{c}\text { CATALOG } \\
\text { NUMBERES }\end{array}$ & $\mid \begin{array}{c}\text { NUMBERS } \\
\text { OT } \\
\text { INDIVID- } \\
\text { UALS }\end{array}$ & $\begin{array}{l}\text { MEAN } \\
\text { FACET } \\
\text { VALETES }\end{array}$ & $\left|\begin{array}{c}\text { MEANS } \\
\text { IN } \\
\text { FACTORAL } \\
\text { UNITS }\end{array}\right|$ & $\mid \begin{array}{c}\text { FACTORIAL } \\
\text { UNITS } \\
\text { FROM } \\
\text { HETERO- } \\
\text { ZYGOTES }\end{array}$ & $\mid \begin{array}{c}\text { DOMI- } \\
\text { NANCE IN } \\
\text { PER } \\
\text { CENTS }\end{array}$ \\
\hline Ultra-bar stock. . & $158-499$ & 1590 & 21.96 & -9.79 & -5.53 & 84.8 \\
\hline Full stock..... & 345 & 10 & 810.6 & +26.67 & +30.93 & 15.2 \\
\hline Heterozygotes. & 357 & 54 & 36.54 & -4.26 & & \\
\hline Low selected bar $\left(\mathrm{F}_{24}\right)$. & 391.2 & 129 & 35.1 & -4.45 & +23.89 & 23.2 \\
\hline Full stock. . . . . . . . . & 345 & 10 & $810: 6$ & +26.67 & -7.23 & 76.8 \\
\hline Heterozygotes... & 769 & 19 & 399.9 & +19.44 & & \\
\hline Ultra-bar stock. & $158-499$ & 1590 & 21.96 & -9.79 & -1.84 & 82.6 \\
\hline Low selected bar $\left(\mathrm{F}_{2}\right)$. & $144-145$ & 179 & 61.8 & +0.74 & +8.69 & 17.4 \\
\hline Heterozygotes....... & 742 & 87 & 25.7 & -7.95 & & \\
\hline
\end{tabular}

change in facet number is not a matter of accretion, but that the whole facet-producing mass is involved. According to this view, the factorial value of the difference between a 50-facet and a 55 -facet individual is the same as that of the difference between a 500- and a 550-facet individual. In other words, an environmental or germinal change in what would otherwise have been a 500-facet stock and which produces instead 550 facets would, if acting upon a 50-facet stock, produce 55 facets and not 100 facets. The ordinary tabulations of variation in which classes have equal character values over the whole range of variation do not give equal factorial values. 
Using factorial values and reducing facet numbers to departures plus or minus from the mean value of the unselected white-bar stock, the following percentage coefficients of dominance were determined:

a. Low selected bar $\left(\mathrm{F}_{24}\right)$ over full eye

$$
\begin{aligned}
& =\frac{\text { full }- \text { heterozygote }}{\text { full }- \text { low selected bar }\left(F_{24}\right)}=\frac{26.67-19.44}{26.67-(-4.45)} \times 100 \\
& =23.2 \text { per cent. }
\end{aligned}
$$

b. Full eye over low selected bar $\left(\mathrm{F}_{24}\right)$

$$
\begin{aligned}
& =\frac{\text { low selected bar }\left(\mathrm{F}_{24}\right)-\text { heterozygote }}{\text { low selected bar }} \text { - full } \\
& =\frac{-4.45-19.44}{-4.45-26.67} \times 100=76.8 \text { per cent. }
\end{aligned}
$$

c. Ultra bar over full eye $=\frac{\text { full }- \text { heterozygote }}{\text { full }- \text { ultra-bar }}$

$$
=\frac{+26.67-(-4.26)}{+26.67-(-9.79)} \times 100=84.6 \text { per cent. }
$$

d. Full eye over ultra-bar $=\frac{\text { ultra-bar }- \text { heterozygote }}{\text { ultra-bar }- \text { full }}$

$$
=\frac{-9.79-(-4.26)}{-9.79-26.67} \times 100=15.4 \text { per cent. }
$$

e. Ultra-bar over low selected bar $\left(\mathrm{F}_{2}\right)$

$$
\begin{aligned}
& =\frac{\text { low selected bar }\left(\mathrm{F}_{2}\right)-\text { heterozygote }}{\text { low selected bar }- \text { ultra-bar }} \\
& =\frac{+0.74-(-7.95)}{+0.74-(-9.79)} \times 100=82.6 \text { per cent. }
\end{aligned}
$$

f. Low selected bar $\left(\mathrm{F}_{2}\right)$ over ultra-bar

$$
\begin{aligned}
& =\frac{\text { ultra-bar }- \text { heterozygote }}{\text { ultra-bar }- \text { low selected bar }\left(\mathrm{F}_{2}\right)} \\
& =\frac{-9.79-(-7.95)}{-9.79-0.74} \times 100=17.4 \text { per cent. }
\end{aligned}
$$

With three genes at the same locus all affecting facet number, it is possible to make the interesting comparisons whose quantitative values have just been determined. Obviously, dominance has been strikingly increased by the change which transformed bar into ultra-bar. Bar pulls full down only 23.2 per 
cent of the distance between the two, while ultra-bar pulls full down 84.6 per cent. Correspondingly, ultra-bar pulls bar 82.6 per cent of the distance between them. The difference in dominance is shown also in the tabulations of the facet values of the daughters of a cross between a heterozygous female and a bar male as compared with the daughters of a heterozygous female with an ultra-bar male (tables 7 and 8 and figs. 6 and 8 ). In the first case (fig. 6) the distribution of values is distinctly bimodal, because the mean values of heterozygous and bar females are far apart. In the second class the distribution is essentially unimodal, because the values of heterozygous and ultra-bar females are close together.

\section{THE LOCATION OF THE ULTRA-BAR GENE}

That the new factor is located in the sex chromosome is indicated by the results of numerous matings as given in tables 8 and 9. Bar females mated with ultra-bar males give intermediate females and bar males (figs. 4 and 5). Heterozygous females mated with bar males give bar and intermediate females and bar and ultra-bar males (figs. 6 and 7). Heterozygous females mated with ultra-bar males give bar and ultra-bar males (fig. 9) and presumably ultra-bar and heterozygous females, though the two populations are so close together that the overlapping gives an approach to a normal variation curve (fig. 8). The compound character of the curve is indicated by its greater variability as compared with either ultra-bar alone or heterozygotes alone, as shown in table 8 .

If ultra-bar is the result of an accessory factor acting in conjunction with an unchanged bar gene, it should be possible by crossing over to separate the two and thus obtain the original bar.

Ultra-bar females crossed with full males give in $F_{1}-\times-$ females and $\stackrel{B^{\prime} U}{-}-$ males. If there is no crossing over $F_{2}$ should $\mathrm{B}^{\prime} \mathrm{U}$ give $\stackrel{B^{\prime} U}{-X}$ or ultra-bar males, $\longrightarrow$ or full males, $\begin{aligned} & -\times- \\ & -\times-\end{aligned}$ 


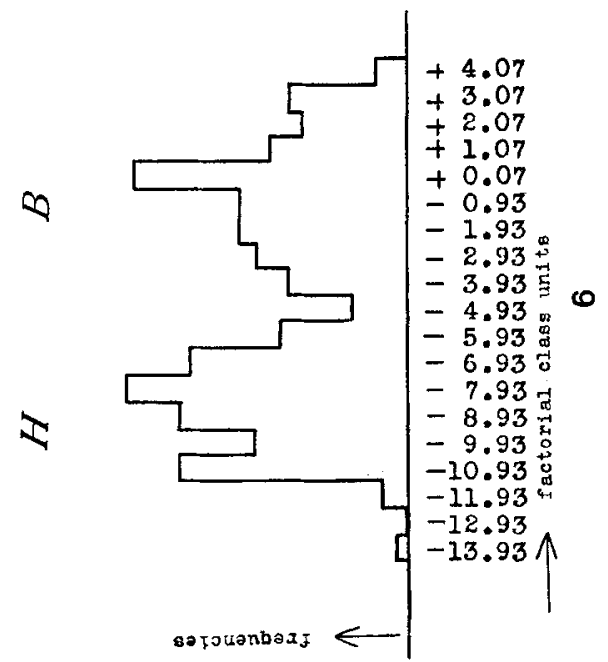

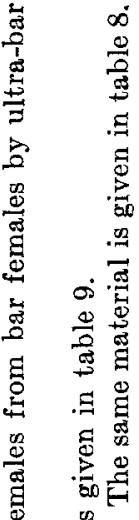
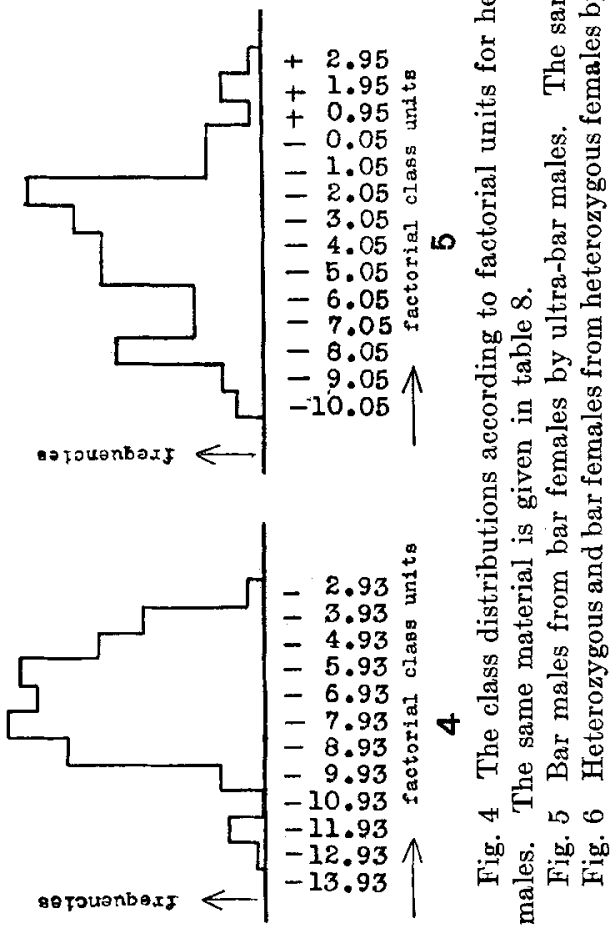
or ultra bar females and $B^{\prime} U$ or heterozygous females with ultra-bar and full-eye factors. If crossing over occurs there should be in addition to the above $-\mathrm{B}^{\prime}$ or bar males, $-\mathrm{U}$ $\mathrm{B}^{\prime}$

or full males with an $U$ accessory factor, $\underset{\substack{-B^{\prime} \text { U }}}{-\times-}$ or heterozygous females with bar and ultra-bar factors and $\begin{gathered}\mathrm{U} \\ -\times-\times- \\ \mathrm{B}^{\prime} \mathrm{U}\end{gathered}$ or heterozygous females with ultra-bar and full factors plus an $\mathrm{U}$ accessory factor.

As bar males are readily distinguishable from ultra-bars, the test of the hypothesis is the presence or absence of bar males in $\mathrm{F}_{2}$. The other differences indicated by the formulae can probably not be detected with certainty as the effect of an accessory $\mathrm{U}$ factor upon full is unknown, the heterozygote between bar and ultra-bar is so close to pure ultra-bar that it cannot be distinguished with certainty and the effect of an extra accessory $U$ upon the heterozygote between ultra-bar and full is unknown.

Full females crossed with ultra-bar males give in $\mathrm{F}_{1}$ heterozygous females and full males. The expected $F_{2}$ males are the same as those in the reciprocal cross. If there is no crossing over, the expected females are $B^{\prime} U$ or heterozygotes with low facet numbers and $=$ or full females. If crossing over occurs there are to be expected in addition to the above $-\mathrm{B}^{\prime}-$ or heterozygotes with high facet number and $\begin{gathered}\mathrm{U} \\ -\mathrm{X} \text { 二 }\end{gathered}$ or full females with a $\mathrm{U}$ accessory factor.

The heterozygotes between ultra-bar and full are so much lower than those between bar and full that the two can be easily differentiated. The facet values of the other differences are unknown. 


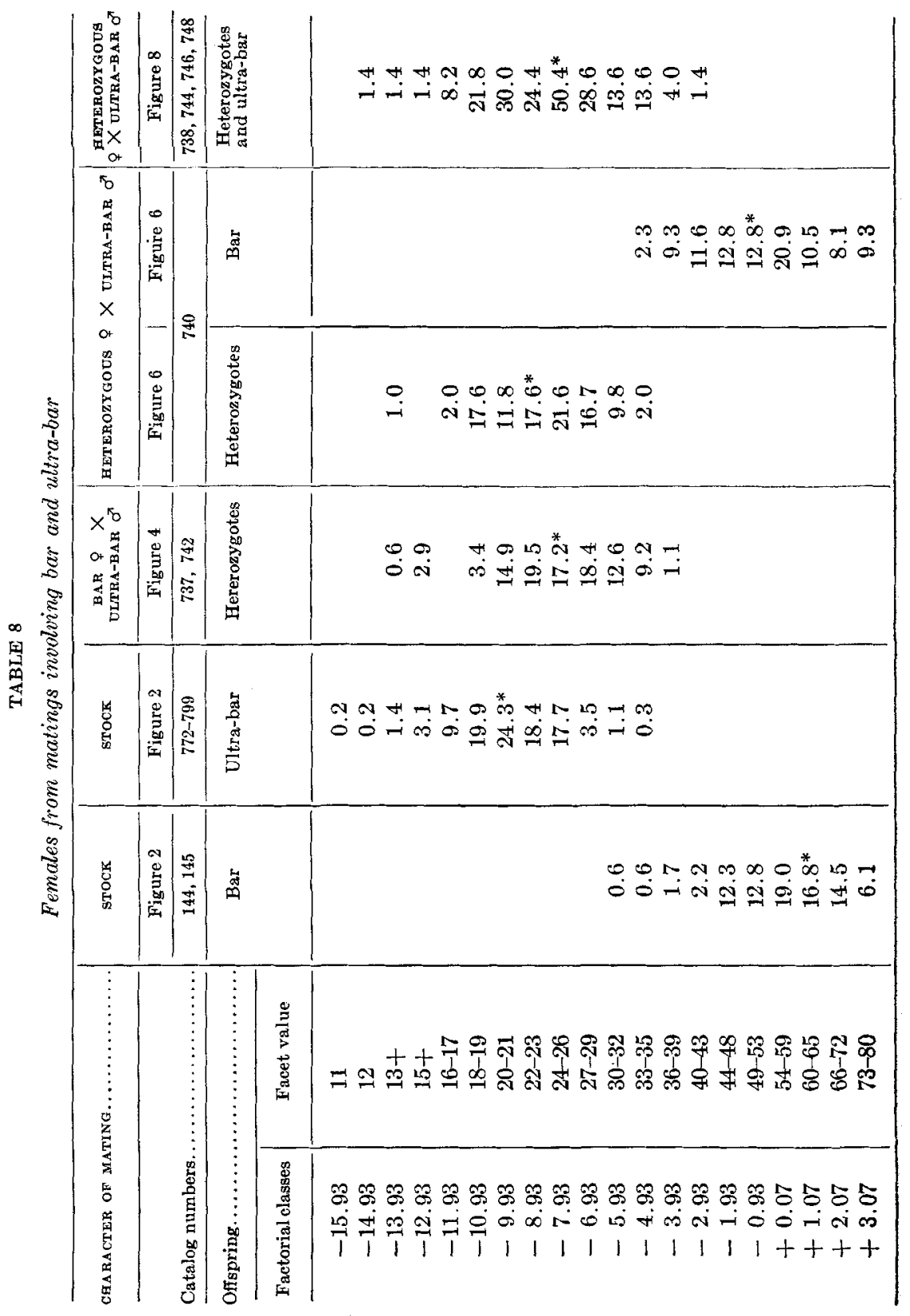


CHANGE IN THE BAR GENE OF DROSOPHILA

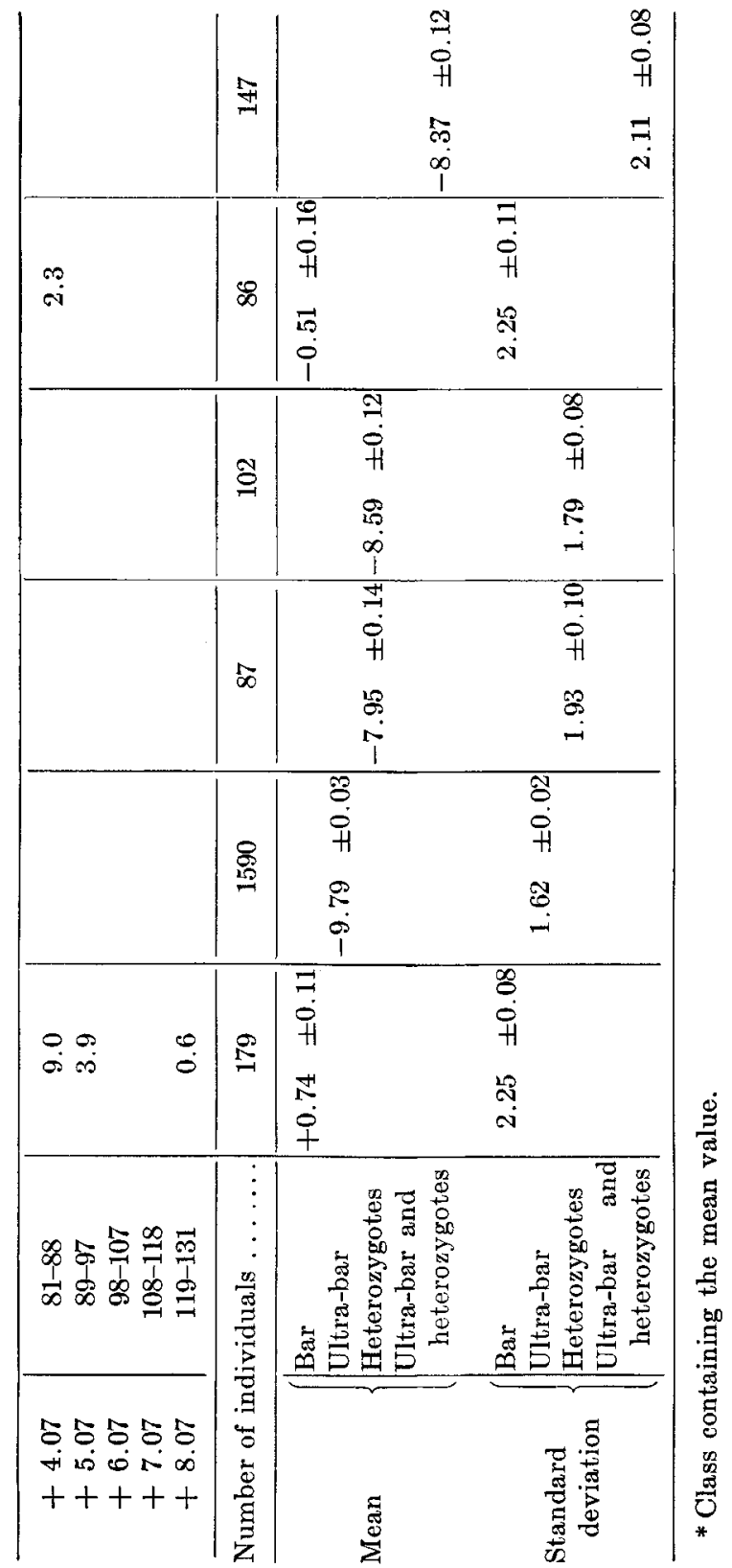




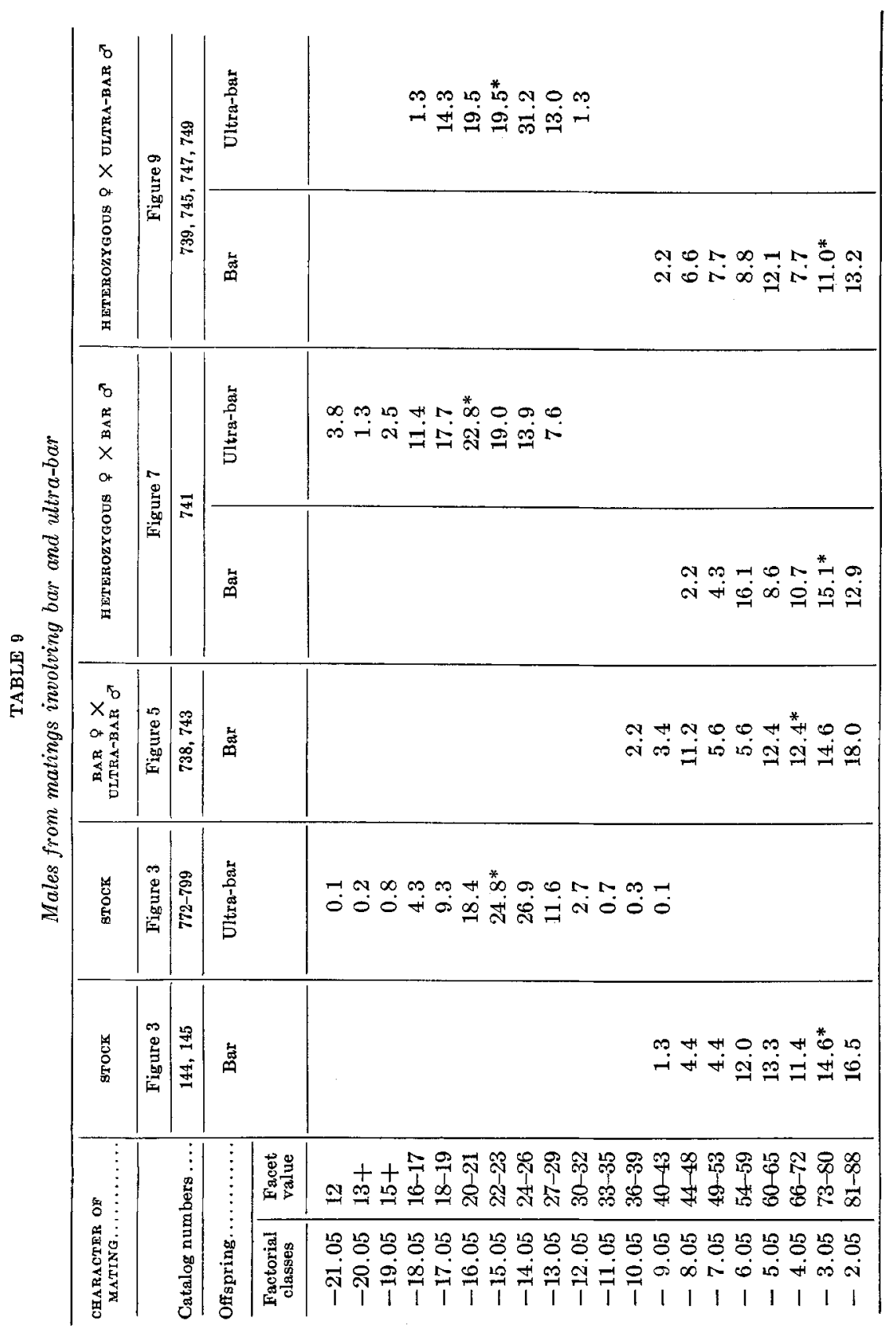




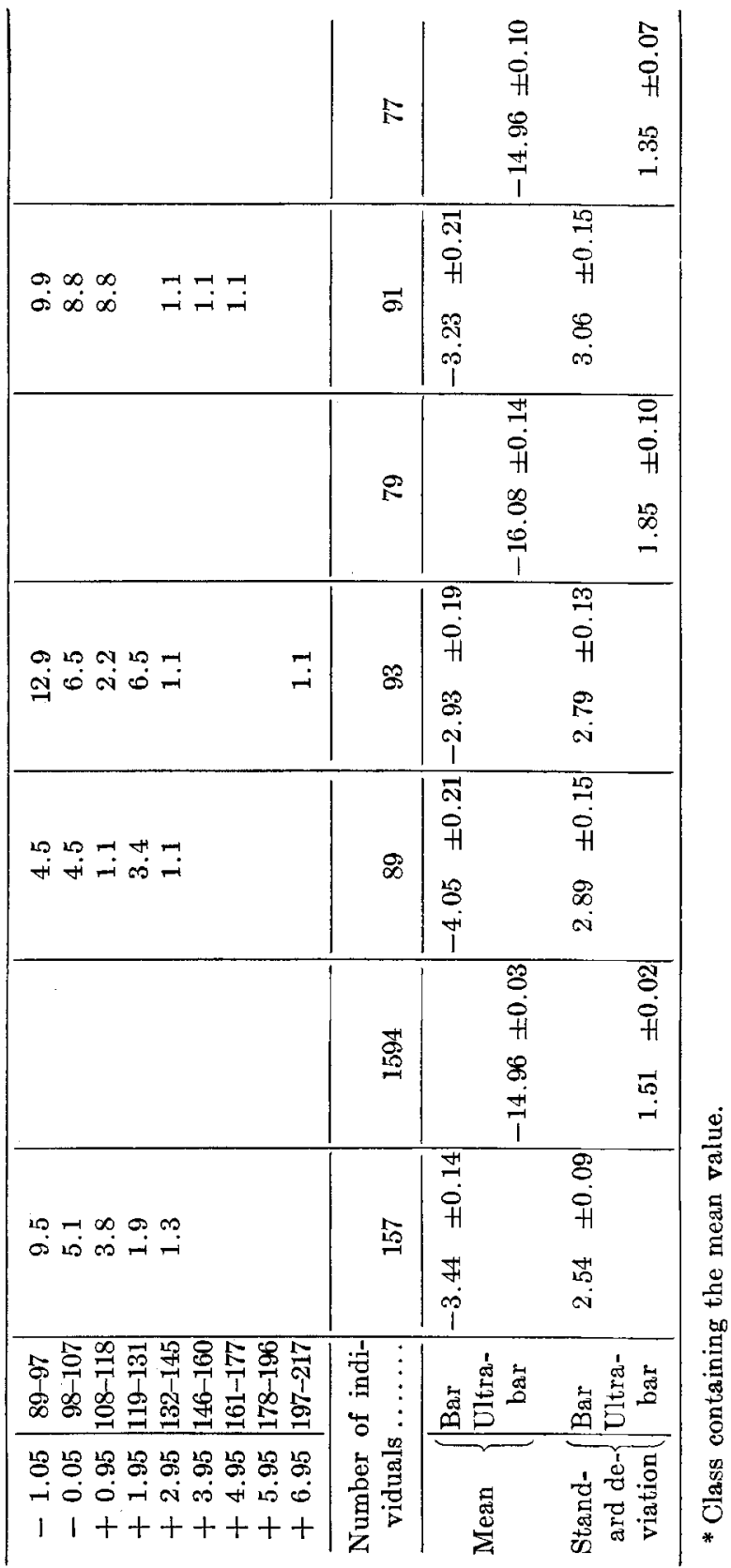




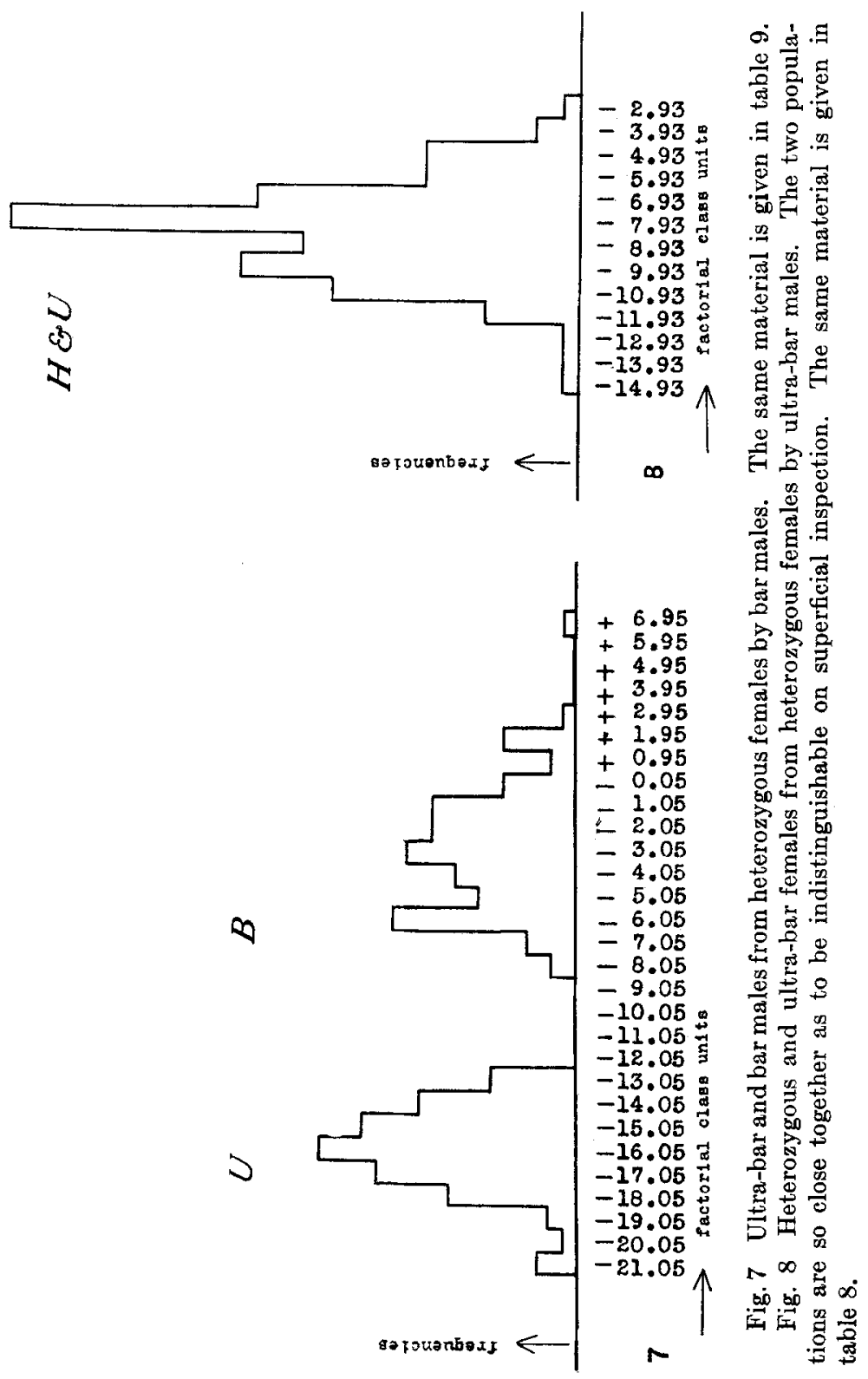


The results of these comparisons are given in table 10. Males with 40 facets or less are listed as ultra-bar and those with a few facets above 40 as ultra-bar + . Those that are considerably above 40 are classed as high males and might have been considered as probably belonging to bar if no tests had been made of them. Among the females are included the heterozygotes. Those that agree in facet number with the heterozygotes of $F_{1}$, having 49 facets or less according to mating no. 357 (table 7), are listed as low heterozygotes. Those that are higher than this

$$
U \quad B
$$

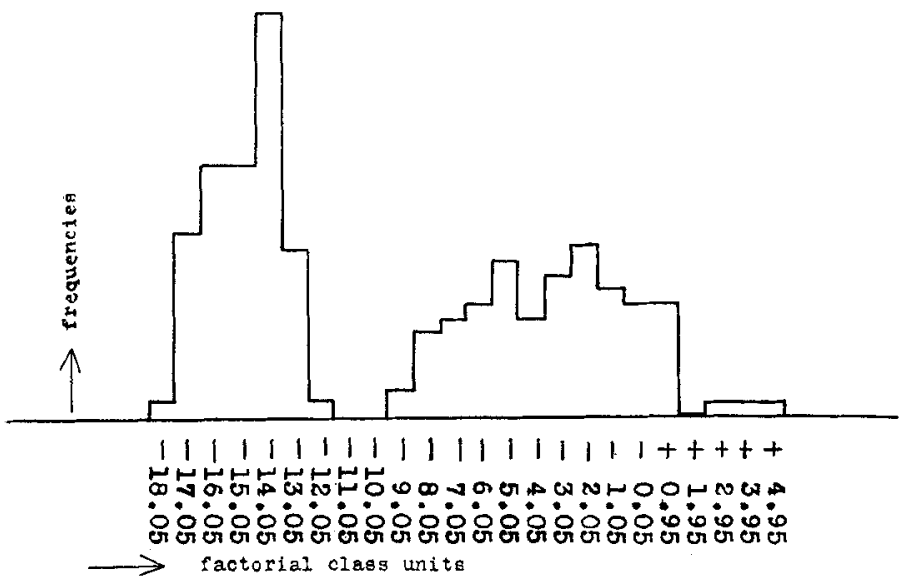

Fig. 9 Ultra-bar and bar males from heterozygous females by ultra-bar males. The same material is given in table 9 .

are put down as high heterozygotes, and without further evidence might have been supposed to have a bar instead of an ultra-bar factor.

TABLE 10

$F_{2}$ from ultra-bar $\times$ full and full $\times$ ultra-bar

\begin{tabular}{|c|c|c|c|c|c|}
\hline & ULTRA-BAR & ULTRA-BAR+ & $\begin{array}{l}\text { TOO HIGH } \\
\text { FOR } \\
\text { OLTRA-BAR }\end{array}$ & $\begin{array}{l}\text { Low } \\
\text { HETEROZY- } \\
\text { GOTES }\end{array}$ & $\begin{array}{l}\text { HIGH } \\
\text { HETEROZY- } \\
\text { GOTES }\end{array}$ \\
\hline $\begin{array}{l}\text { Males. . . . . . . } \ldots \ldots \ldots \\
\text { Females . . . . . } \ldots \ldots \ldots\end{array}$ & 1235 & 3 & 3 & 553 & 4 \\
\hline
\end{tabular}


Among the $\mathrm{F}_{2}$ males of both the reciprocal crosses there are 1235 males within the range of ultra-bar, three of which come just above this range having respectively 42,42 , and 44 facets, and three which are considerably higher having 51, 60, and 88 facets. Of the first three, one of the 42-facet males was tested by crossing to full and shown by its dominance to be an ultrabar. It is probable from this and other evidence that this slight extension of the range of ultra-bar is due to accessory factors introduced by the full stock. The other three males are of a different character. The 60 -facet male died without a test. The 51- and 88-facet males when mated to full gave heterozygotes which were higher than those of ultra-bar $\times$ full, but on the other hand lower than those of bar $\times$ full. These heterozygotes agree in character with those of the mutant in the pure ultrabar stock which was described above on p. 308. The high exceptional males cannot therefore be considered as bar males produced by the separation of the $\mathrm{U}$ factor from $\mathrm{B}^{\prime}$ by crossing over.

Among the $\mathrm{F}_{2}$ females of the cross between full females and ultra-bar males there are 553 with the characteristics of typical. low heterozygotes of the $\mathrm{F}_{1}$ generation and four with higher facet numbers. One of the latter has 154 facets and is considerably below the range of heterozygotes between full and bar as given in table 9. The other three females come within this range. The one which was tested by crossing to full, however, gave only ultrabar and full males instead of bar and full as its facet number seemed to indicate that it should give. It is therefore an instance of failure of the ultra-bar factor to dominate full in the ordinary manner. As in the case of the males, crossing over cannot be given as an explanation of these exceptional females, though it is unfortunate that some of them died before a test could be made. However, even if all the exceptional untested males and females were classed as bars produced by crossing over of an assumed accessory ultra-bar factor, the locus of this factor would have to be placed very close to bar. Absolute proof is impossible because it can always be held that the new gene is so close to the old one that crossing over cannot certainly be expected in any 
practicable number of individuals. Besides there may be a nocrossover' accessory factor.

The reasonable conclusion to be drawn from the evidence is that ultra-bar has the same locus as bar or a locus so close to it that the two are a single unit in all demonstrable cases. It follows that ultra-bar has been produced by a change in the bar gene, and not by a change at some other locus.

\section{CONCLUSIONS}

Eye-facet number in Drosophila furnishes an excellent material for the quantitative study of both germinal and environmental factors. The demonstration of the striking and regular temperature effect makes possible the recognition and analysis of germinal factors. As outlined in preliminary reports (see bibliography) selection for facet number in bar-eye has shown that the effect of selection here is the result, first, of a sorting out of germinal diversities in the original stock and, second, of the isolation of new diversities as they arise. Besides occasional reverse mutations to full, the original diversities as well as the new changes have been due to accessory factors. The mutation described in the present paper, however, resembles the reverse mutations in that it involves change in the bar gene. The effect here, however, is essentially an intensification of that produced by bar. There is further decrease in facet number and a great increase in dominance.

It is interesting to note also that the change occurred in a line in which low selection was being carried on. In the light of all the evidence concerning the direction of mutations, no special significance can be attached to this fact at present. For instance, reverse mutations to full occur in the low selection lines of bar and in ultra-bar as well as in the high selection lines. While, therefore, a connection between the direction of selection and the direction of mutations in general seems improbable, the matter is of sufficient importance to warrant careful record of all instances. 
The constancy of the new gene seems to be of about the same order as that of bar. Reverse mutations to full occur in both. In ultra-bar there is also a reverse mutation in the direction of bar, but apparently not to the same point because, while the mutant comes within the facet range of bar, it does not have the same dominance over full.

The locus of the new gene is the same as that of bar or is so close to it that our methods of analysis are not capable of separating the two. The crossing-over test is the only one that can be applied, and it has the obvious difficulties due to the improbability of any crossing over between two genes which are very close together, and it is also subject to the criticism that the crossing over may itself be inhibited by an accessory factor. However, it is our only test and its findings must be taken at their face value.

In the particular test applied, the presence or absence of crossing over in $F_{2}$ of crosses between ultra-bar and full, a few individuals appeared which came within the facet range of bar. The untested ones might of course have been bar. It is unfortunate that absolute certainty was not obtained because of the interest in progressive changes of the genes. Most of the progressive changes in characters observed in Drosophila are due to accessory factors and not to changes in a single gene.

The presence of three genes at the same locus made possible an attempt to see if ultra-bar bears a direct quantitative relation to bar. If this is true, it might be considered as merely two or more bar units closely held together. The values for full, full $\times$ bar, bar, ultra-bar $\times$ full, ultra-bar $\times$ bar, and ultra-bar females could in that case be represented as resulting from different amounts of a common inhibitor of facet number and there should be a consistent relation in the facet values. This, however, is not true, and it seems probable therefore that the change from bar to ultra-bar is specific and not merely a quantitative intensification of the bar factor. 


\section{SUMMARY}

1. The recognition of a pronounced and regular effect of temperature upon facet number in Drosophila has made possible a more accurate analysis of the germinal changes taking place in the bar-eyed races.

2. A single male with but 19 facets appeared in the second generation of downward selection in white bar, the normal range of that generation being 41 to 134 facets.

3. From this single male there was derived by crossing with his sisters a new race which has been called ultra-bar. The symbol for its gene is $\mathrm{B}^{\prime} \mathrm{U}$.

4. The mean facet value of the males of this race is 23 as compared with 75.6 in the parental stock.

5. The ranges of ultra-bar and bar do not overlap in the males and barely overlap in the females.

6. The new stock has remained unchanged for over twenty months except for the appearance of a few individuals with marked departures from the normal range.

7. Among these mutations there have appeared reversals to full-eye and returns to a condition resembling bar in facet number, but differing from it in dominance.

8. Ultra-bar differs strikingly from bar in having a mueh greater dominance over full, 84.8 per cent as compared with 23 per cent.

9. Correspondingly ultra-bar has a dominance of 82.6 per cent over bar.

10. The ultra-bar gene is located in the sex chromosome.

11. Crossing-over tests show that the new gene has the same locus as bar or is so close to it as to be identical for all practical purposes.

12. The change involved is to be considered as a change in the bar gene itself which is in the direction of the original change from full to bar.

13. The dominance relations, however, make it improbable that ultra-bar can be considered merely as a quantitative increase in the bar reaction. 
14. The fact that ultra-bar occurred in the course of a downward selection of bar is interesting, though probably not significant, in view of other mutations affecting facet number which have not always been in the direction of selection.

\section{Acknowledgments}

In common with other students of Drosophila, I have had the generous help with materials and suggestions of Prof. T. H. Morgan and Drs. A. H. Sturtevant and C. B. Bridges. It is a pleasure also to express my indebtedness to Dr. Joseph Krafka, Jr., to whose untiring care of the stocks and tests the success of these experiments is largely due. I am also under obligation to Prof. A. R. Crathorne, who was kind enough to go over the method of factorial units which I have used in tabulating the data.

\section{BIBLIOGRAPHY}

KRAFKA, Joseph, JR. 1920 The effect of temperature upon facet number in the bareyed mutant of Drosophila melanogaster, J. Gen. Physiol., v. 2.

MAT, H. G. 1917 Selection for higher and lower facet numbers in the bar-eyed race of Drosophila and the appearance of reverse mutations. Biol. Bull., vol. 33, pp. 361-395.

Sexster, E. W. 1919 Eye-facet number as influenced by temperature in the bar-eyed mutant of Drosophila melanogaster (ampelophila). Biol. Bull., vol. 37, pp. 168-182.

Trce, S. A. 1914 A new sex-linked character in Drosophila. Biol. Bull., vol. 26, pp. 221-230.

ZELENY, C. 1917 Full-eye and emarginate eye from bar-eye in Drosophila without change in the bar gene. Abstracts of papers read before the fifteenth annual meeting of the American Soc. of Zoologists at Minneapolis, p. 7 ; Anat. Rec., vol. 14, p. 89.

1917 Selection for high-facet and low-facet number in the bar-eyed race of Drosophila. Abstracts of papers read before the fifteenth annual meeting of the American Society of Zoologists, Minneapolis, p. 9, Anat. Rec., vol. 14, p. 91.

1918 Germinal changes in the bar-eyed race of Drosophila during the course of selection for facet number. Proc. Indiana Acad. Sc., 1917, pp. $73-77$.

1919 A change in the bar gene of Drosophila involving further decrease in facet number and increase in dominance. Journ. Gen. Physiol., vol. 2 , pp. $69-71$.

Zelent, C., AND Matroon, E. W. 1915 The effect of selection upon the 'bar eye' mutant of Drosophila. J. Exp. Zool., vol. 19, pp. 515-529. 